\title{
Rapid Quantitative Assessment of Rhizoctonia Resistance in Roots of Selected Wheat and Barley Genotypes
}

Patricia A. Okubara, USDA-ARS, Root Disease and Biological Control Research Unit, Pullman, Washington 99164-6430; Natalie Leston, Department of Plant Pathology, Washington State University, Pullman, Washington 99164-6430; and Ute Micknass, Karl-Heinz Kogel, and Jafargholi Imani, Institute of Phytopathology, Research Centre for BioSystems, Land Use, and Nutrition (IFZ), Justus Liebig University, D-35392 Giessen, Germany

\begin{abstract}
Okubara, P. A., Leston, N., Micknass, U., Kogel, K.-H., and Imani, J. 2016. Rapid quantitative assessment of Rhizoctonia resistance in roots of selected wheat and barley genotypes. Plant Dis. 100:640-644.

Rhizoctonia solani AG8, causal agent of Rhizoctonia root rot and bare patch in dryland cereal production systems of the Pacific Northwest United States and Australia, reduces yields in a wide range of crops. Disease is not consistently controlled by available management practices, so genetic resistance would be a desirable resource for growers. In this report, we describe three rapid and low-cost assays for $R$. solani AG8 resistance in wheat and barley, with the view of facilitating screens for genetic resistance in these hosts. The first assay uses $50-\mathrm{ml}$ conical centrifuge tubes containing soil infested with $R$. solani AG8 on

a substrate of ground oats. The second assay uses roots of 3-day-old seedlings directly coated with infested ground oats, followed by incubation in plastic dishes. The third assay, suitable for barley, uses whole infested oat kernels in 50-ml tubes. Symptoms are quantified on the bases of root fresh weight and total root length at 7 and 3 days for the tube and coating assays, respectively. Each of the assays show the same disease differential between susceptible and partially resistant wheat genotypes. The assays can be conducted in the laboratory, growth chamber, or greenhouse.
\end{abstract}

Rhizoctonia solani Kühn AG8 (teleomorph Thanatephorus cucumeris [Frank] Donk) is among several soilborne necrotrophic fungi that cause 10 to $15 \%$ yield reductions in dryland cereal productions systems of the Pacific Northwest, United States (PNW) and Australia (Cook et al. 2002; MacNish and Neate 1996). In direct-seeded fields harboring high levels of pathogen inoculum, bare patches as the result of plant death can account for even greater yield losses (MacNish and Lewis 1985; Paulitz et al. 2002; Schroeder and Paulitz 2006). Rhizoctonia root rot of wheat and barley are not adequately controlled by fungicides, the broad host range of $R$. solani AG8 precludes rotation as an effective control measure in most cases, and the efficacy of beneficial antagonists (Sharma et al. 2008) must be further explored. Application of nitrogen at the time of seeding, herbicide-based reduction of weeds and volunteers that harbor the pathogen, and tillage are the most effective control measures (Babiker et al. 2011; Paulitz et al. 2002). Tillage also can reduce disease pressure through disruption of the fungal population on debris in the soil (Gill et al. 2002; Pumphrey et al. 1987), but the potential for wind and soil erosion and water loss due to tillage-induced disturbance of soil structure offsets the benefits of retaining surface residue (Bockus and Shroyer 1998).

Corresponding author: P. A. Okubara. E-mail: patricia.okubara@ars.usda.gov

References to a company and/or product by the USDA are only for the purposes of information and do not imply approval or recommendation of the product to the exclusion of others that may also be suitable. USDA is an equal opportunity provider and employer.

Accepted for publication 10 July 2015.

http://dx.doi.org/10.1094/PDIS-05-15-0611-SR

This article is in the public domain and not copyrightable. It may be freely reprinted with customary crediting of the source. The American Phytopathological Society, 2016.
Genetic resistance to Rhizoctonia in small-grain cereals is not currently available to breeders and growers (Okubara and Jones 2011; Okubara et al. 2009; Smith et al. 2003). Nonetheless, host genetic resistance is viewed as a sustainable means of disease control that would afford constitutive protection of roots and potentially increase grain yield in conservation tillage systems (Bockus and Shroyer 1998). Novel genetic resistance is being characterized in synthetic hexaploid wheats, in which the ABD genome composition has been constituted by fusing nuclei of $\mathrm{AB}$ and $\mathrm{D}$ parents using cytogenetics (Dreisigacker et al. 2008). Identifying Rhizoctonia resistant and susceptible individuals in mapping populations (A. Mahoney and S. Hulbert, unpublished) would be facilitated by a screening protocol with the capacity to evaluate several hundred individuals per month in the period between annual selections in the field.

To develop more rapid Rhizoctonia resistance assays, we tested several modifications to an earlier protocol in which an individual seedling was challenged in a plastic Cone-tainer (Stuewe and Sons, Talent, OR; soil capacity $\sim 70 \mathrm{~g}$ ) over a 14-day period (Okubara and Jones 2011; Okubara et al. 2009). A lengthwise cut was made in each cone-tainer and closed with duct tape before use so that at the time of harvest the plastic could be peeled back without damage to the roots. We also sought to design a protocol for screening transformed barley roots, as a way to assess candidate resistance genes without first having to invest the time needed to generate transformed wheat or barley plants. To these ends, we tested different forms of inocula, soil volumes, and assay times on selected wheat and barley genotypes. As an indicator of success, we monitored differential disease and root development in susceptible versus partially resistant control genotypes of wheat previously screened in cone-tainer assays (Okubara et al. 2009).

\section{Materials and Methods}

Wheat cultivars and pathogen inocula. Cultivar Scarlet, a hard red spring wheat, is susceptible to $R$. solani AG8, and displayed stunting and brown lesions upon infection. An ethyl methane 
sulfonate (EMS)-induced Scarlet mutant, called Scarlet Rz-1 (Rz1), is partially resistant to $R$. solani AG8 in the greenhouse (Okubara et al. 2009). Families of $\mathrm{BC}_{2} \mathrm{~F}_{7}$ (recurrent parent Scarlet) seed of Rz1 were used for the assays. Susceptible barley cv. Golden Promise was tested in parallel experiments; a resistant barley line was not available. For pathogenicity assays, wheat and barley seeds were gently agitated in deionized tap water for 25 to $30 \mathrm{~min}$, rinsed three times, and germinated in plastic petri plates lined with Whatman \#1 or \#4 filter paper at $25 \pm$ (s.d.) $1{ }^{\circ} \mathrm{C}$ in darkness.

$R$. solani AG8 isolate C1 (Weller et al. 1986) was used for all experiments. The fungus was propagated on potato dextrose agar (PDA; Difco, Sparks, NV). Oat kernels were infested with $R$. solani AG8 as previously described (Okubara et al. 2009; Schroeder and Paulitz 2008), except that the dry oat seeds were collected on a $1-\mathrm{mm}$ diameter sieve to remove debris, and $200 \mathrm{ml}$ of sieved oats were suspended in $150 \mathrm{ml}$ of deionized tap water prior to autoclaving. Oat kernels were evenly covered with mycelia after 3 weeks of growth at 22 to $25^{\circ} \mathrm{C}$, and were not shaken immediately before drying. Controls consisted of autoclaved and dried oats that were not infested with the pathogen. Colonized and noninfested oats were ground in coffee grinders and propagules were enumerated by plating on selective medium (Okubara et al. 2009; Schroeder and Paulitz 2008). To minimize contamination, the noninoculated oats were ground immediately before use.

For whole oat kernel assays, a portion of kernels was set aside from each batch without grinding. Twelve kernels were randomly selected from each batch and placed on two plates of PDA (6 kernels per plate); growth of $R$. solani from kernels was monitored over a 3-day period. Inoculated and noninoculated oat materials were usable for up to 3 weeks if stored at $-20^{\circ} \mathrm{C}$.

Soil assays with ground oat inoculum. $R$. solani AG8 inoculum in ground oats was mixed with a soil/sand mixture (1:1 by volume) at a final population density of $400 \mathrm{CFU} / \mathrm{g}$ soil. For wheat assays, the soil/sand mixture (1:1 by volume) consisted of native grassland soil from Lind, WA (coarse silt loam; Schillinger et al. 2012), and Sakrete Natural Play Sand (playground grade; Bonsal American, Inc., Charlotte, NC). A diagram of the ground oat assay is shown in Figure 1A. About $35 \mathrm{ml}$ of the soil mixture was transferred to a 50-ml disposable conical centrifuge tube and tapped repeatedly to remove air pockets. Approximately $8 \mathrm{ml}$ of metalaxyl solution (75 mg/liter a.i., Novartis, Greensboro, NC) was added to each tube, depending on soil moisture content, so that the mixture was uniformly wet but had no standing liquid. A single seedling was placed on the surface and covered with $5 \mathrm{ml}$ of noninoculated sand. Seedlings having root lengths of 0.8 to $1.0 \mathrm{~cm}$ were optimal for planting in 50-ml tubes. To obtain optimal root lengths, germination was carried out for about $52 \mathrm{~h}$ for Scarlet, $60 \mathrm{~h}$ for Rz1, and 40 to $42 \mathrm{~h}$ for Golden Promise. Plants were grown at $15 \pm 1^{\circ} \mathrm{C}$ under 16:8 h light/dark for 7 days. Two to three milliliters of water was added to each tube on day 4 if needed. About $5 \mathrm{ml}$ water was added to each tube for 30 to $60 \mathrm{~min}$ to loosen the soil and minimize root breakage at the time of harvest. Roots were carefully separated from soil using a spoon-type spatula. Eight control and 12 pathogenchallenged seedlings were evaluated in each experiment. The experiment was repeated twice.

Whole oat kernel soil assays. The inoculum used in these assays consisted of a single oat kernel infested with the pathogen placed directly under the seedling. A diagram of the kernel assay is shown in Figure 1B. The procedure for barley assays was similar to that described in the previous section, except that the sand was autoclaved, the soil was a potting mixture containing low phosphorus (Archut Fruhstorfer Erde, Type P, HAWITA Gruppe Lauterbach, Germany), and deionized tap water was substituted for the metalaxyl solution. Plants were grown at $15 \pm 1{ }^{\circ} \mathrm{C}$ under $12 \mathrm{~h} \mathrm{light/dark}$ for 7 days. No water or nutrient solution was added during the growth period. Eight control and eight pathogen-challenged seedlings were evaluated in each experiment. The experiment was repeated once.

Root coating assays. Wheat or barley seedlings having roots of about $1.5 \mathrm{~cm}$ in length were selected for root coating assays. Roots were coated with the same ground oat inoculum used for infested soil assays. Controls consisted of noninfested ground oats. Forceps were used to grasp the seed portion of the seedling, then roots were gently touched to or dipped in ground oat material in a petri plate. The seedling was inverted and dipped again so the root system was coated as completely as possible (Fig. 2A). Coated seedlings were transferred to new petri plates lined with moist filter paper, and incubated at $15 \pm$ $1{ }^{\circ} \mathrm{C}, 16: 8 \mathrm{~h} \mathrm{light/dark}$ (wheat) or $12 \mathrm{~h}$ light/dark (barley) for $96 \pm 1 \mathrm{~h}$ for $72 \mathrm{~h}$. The amount of ground oat material (mg) on roots was estimated by weighing 10 to 12 seedlings each of Scarlet and Rz1 before and after coating. Eight to 12 control and 12 to 15 pathogen-challenged seedlings were evaluated in each experiment. The experiment was repeated four times for wheat and three times for barley to demonstrate that the assays were reproducible.

Root growth variables and statistics. Sample sizes represented the minimum number of seedlings needed to reduce the standard

\section{A Ground oat inoculum}

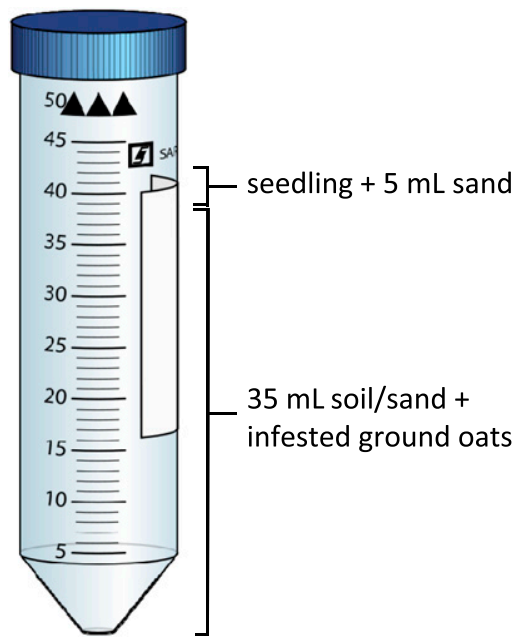

B Whole oat kernel inoculum

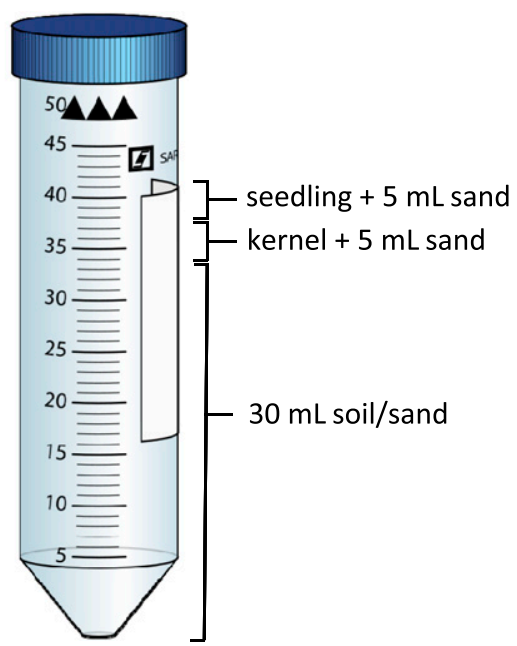

Fig. 1. Assembly of Rhizoctonia root rot resistance assays in 50-ml tubes for A, wheat genotypes using soil infested with ground oat inoculum, or B, barley genotypes using whole oat kernel inoculum. Seedlings and pathogen were placed as indicated in 1:1 (by volume) soil/sand mix, and incubated at $15^{\circ} \mathrm{C}$ under $16: 8 \mathrm{~h} \mathrm{light/dark}$ for 7 days for wheat, and $12 \mathrm{~h}$ light/dark for 7 days for barley. 
errors of the means so that trends in responses to infection could be assessed; 8 to 12 control and 12 to 15 pathogen-challenged seedlings were used. Shoot length $(\mathrm{cm})$, root fresh weight $(\mathrm{mg})$, total root length $(\mathrm{cm})$, surface area $\left(\mathrm{cm}^{2}\right)$, and average diameter $(\mathrm{mm})$ data were collected for seedlings grown in 50-ml tubes. The latter three variables were obtained from digital images of washed roots using WinRHIZO 2004b (Okubara et al. 2009). Root fresh weight and total root length were quantified for coated roots.

Host genotype by pathogen/control combination constituted a treatment. Mean values for root fresh weight $(\mathrm{mg})$, total root length $(\mathrm{cm})$, and root surface area $\left(\mathrm{cm}^{2}\right)$ were determined for each treatment using ANOVA (Statistix vers. 8.1, Analytical Software, Tallahassee, FL). Significant differences among means were determined using Fisher's protected least significant difference test at $P<0.05$. For ground oat soil assays of wheat, Bartlett's $t$ test for homogeneity of variances (Statistix vers. 8.1) was applied to root fresh weight and total root length values to determine if data from two experiments could be combined.

\section{Results}

The procedure used to generate oat inocula resulted in good infection potential and consistent infection. We found that collecting dry oats over a 1-mm diameter sieve removed unwanted material in certain lots of seed. Reducing the volume of water normally used to suspend the oats before autoclaving reducing the clumping of wet oats to the side of the glass flask during incubation, and resulted in more even distribution of mycelia throughout the substrate during the 3-week incubation period. Furthermore, growth on PDA of $R$. solani AG8 from all oat kernels was robust and uniform for each batch (flask) of inoculum.

Assays in 50-ml tubes. Seedlings grown for 7 days in soil infested with ground oat inoculum displayed reductions in differential mean root fresh weight and total root length (Table 1). A significant
A Wheat seedlings
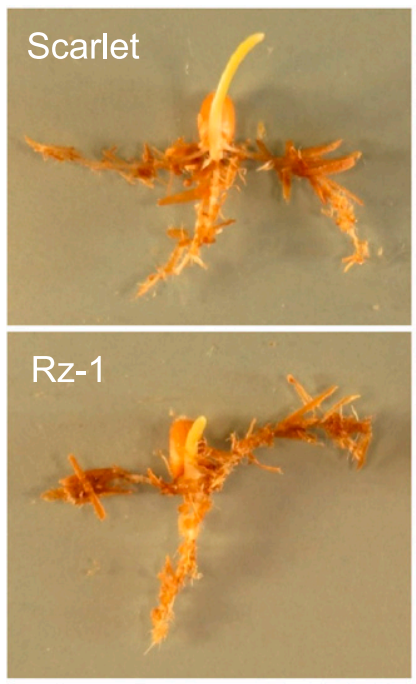

B Barley roots after treatment

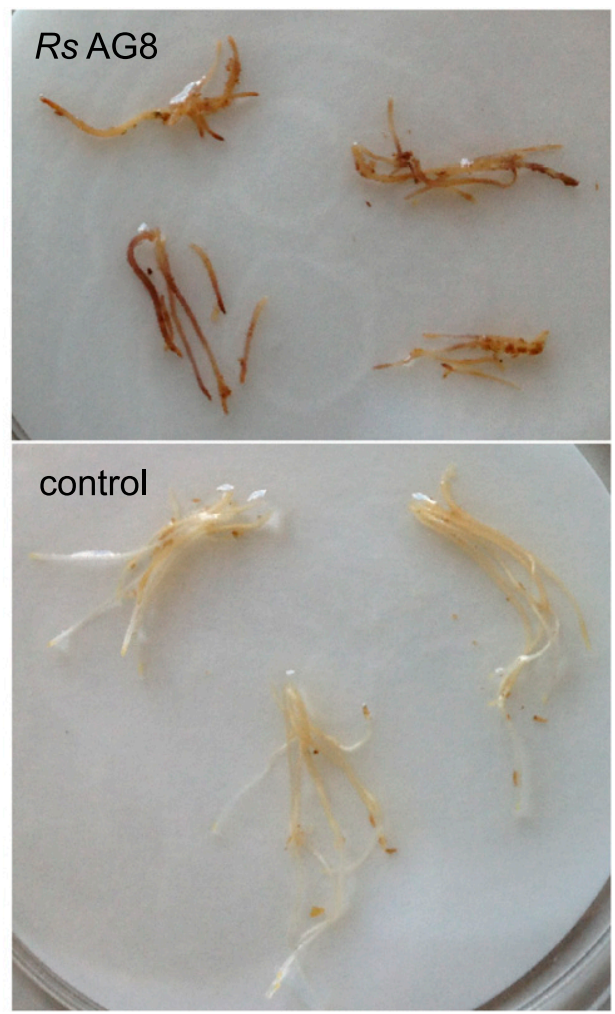

Fig. 2. Root coating of wheat and barley seedlings. A, An example of the root coverage by noninfested ground oat material on roots of wheat cvs. Scarlet (top) and Scarlet-Rz1 (bottom). Each root system was coated with 130 to $150 \mathrm{mg}$ of ground material. B, Discoloration and stunting of excised roots of barley cv. Golden Promise 3 days after dipping in pathogen-infested (top) or noninfested ground oats (bottom).

Table 1. Root responses of wheat cultivars 'Scarlet' (susceptible) and 'Scarlet-Rz1' (partially resistant) to Rhizoctonia solani AG8 after 7 days in ground oat inoculum soil assays

\begin{tabular}{|c|c|c|c|c|c|c|}
\hline Genotype treatmenty & Fresh wt (mg) & Fw ratio ${ }^{z}$ & Root length (cm) & RI ratio ${ }^{z}$ & Surface area $\left(\mathrm{cm}^{2}\right)$ & Sa ratio ${ }^{z}$ \\
\hline \multicolumn{7}{|l|}{ Scarlet } \\
\hline Control & $77 \mathrm{a}$ & - & $51.4 \mathrm{a}$ & - & $6.82 \mathrm{a}$ & - \\
\hline R. solani & $43 \mathrm{c}$ & 0.56 & $26.9 \mathrm{c}$ & 0.52 & $3.89 \mathrm{c}$ & 0.57 \\
\hline \multicolumn{7}{|l|}{ Scarlet-Rz1 } \\
\hline Control & $85 \mathrm{a}$ & - & $48.4 \mathrm{a}$ & - & $6.97 \mathrm{a}$ & - \\
\hline R. solani & $58 \mathrm{~b}$ & 0.69 & $31.4 \mathrm{~b}$ & 0.65 & $4.82 \mathrm{~b}$ & 0.69 \\
\hline
\end{tabular}

y Sample size $=8$ for controls and 12 for $R$. solani AG8 treatments. Letters indicate significant $(P<0.05)$ differences among means within each column according to Fisher's least significant difference test (Statistix vers. 8.1, Tallahassee, FL). Data from two experiments were combined on the basis of Bartlett's $t$ test for homogeneity of variances (Statistix vers. 8.1)

${ }^{\mathrm{z}}$ Ratio of values for fresh wt (Fw), root length (Rl), and surface area (Sa) from $R$. solani-treated relative to control seedlings. 
$(P<0.05)$ difference between mean root length of Rz1 and Scarlet was not always observed using a sample size of 12 . However, we observed that mean root surface area, the product of root length $\times$ root diameter, and mean average root diameter were consistently higher for Rz1; these variables appeared to be better predictors of resistance in sample sizes of 12 .

Reduction in mean root fresh weight and total root length were observed for susceptible barley cv. Golden Promise using whole oat kernels infested with $R$. solani AG8 (Table 2). One of two experiments is shown. Use of whole kernels saved time otherwise spent on grinding and sieving oat kernels, and enumerating propagules. We were also interested in testing the vigor and uniformity of infection of the pathogen from whole kernels relative to dispersed propagules in soil. The experiments showed that susceptible barley was infected to the desired extent with whole kernels; that is, the means of root growth variables of pathogen-challenged seedlings were about $50 \%$ that of control seedlings. Furthermore, a sample size of eight seedlings gave a uniform pathogen response, without much within-treatment variation, as reflected in the standard deviations and standard errors of the means. This finding suggests that trends in pathogen response between genotypes can be quantified with whole kernels using fewer samples.

When the single kernel assay was applied to the wheat genotypes, their roots did not grow past the oat kernel. Roots of control seedlings were also stunted, indicating that the cause was in part physical and not entirely pathogen-associated. Root growth of both genotypes, with and without pathogen challenge, was not sufficient to result in a significant $(P<0.05)$ disease differential. We placed the oat kernel in the middle of the soil/sand column in a separate experiment, but obtained less disease than was desirable (data not shown). The whole kernel assays were rejected for the wheat genotypes used in this study.

Root coating assays. In anticipation of screening intragenic roots of barley and wheat lines for resistance to soilborne fungal pathogens, we developed an assay in which seedling roots were dipped in ground oat inoculum of $R$. solani AG8. Seminal roots of Scarlet and Rz1 after coating are shown (Fig. 2A). Wheat or barley seedlings having roots of about $1.5 \mathrm{~cm}$ in length were ideal for coating. The roots were rapidly growing, yet consistently retained the ground material. Seedlings of Golden Promise had five to six seminal roots compared with three roots for wheat, and showed stunting and a strong browning response to $R$. solani AG8 (Fig. 2B). Each root system retained 130 to $150 \mathrm{mg}$ of ground oat material containing about 40 propagules of the pathogen, as estimated from propagule counts on Rhizoctonia selective medium.

Roots of Rz1 coated with pathogen-infested ground oat showed significant $(P<0.05)$ differences from those of Scarlet in mean root fresh weight and total root length after 3 days of infection (Table 3), typical responses for these genotypes. The roots of noninoculated Rz1 were larger than those of Scarlet, as observed in the tube assays. Golden Promise also showed a significant reduction in root fresh weight and total root length after pathogen challenge (Table 3).

\section{Discussion}

Susceptible Scarlet and partially resistant Rz1 seedlings grown for 7 days in soil infested with ground oat inoculum displayed the pattern

Table 2. Root responses of susceptible barley cultivar Golden Promise to Rhizoctonia solani AG8 in whole oat kernel assays ${ }^{\mathrm{y}}$

\begin{tabular}{lcccc}
\hline Treatment & $\begin{array}{c}\text { Fresh } \\
\text { weight }(\mathbf{m g})\end{array}$ & Fw ratio $^{\mathbf{z}}$ & $\begin{array}{c}\text { Root } \\
\text { length }(\mathbf{c m})\end{array}$ & Rl ratio $^{\mathbf{z}}$ \\
\hline Control & $167 \mathrm{a}$ & - & $166.5 \mathrm{a}$ & - \\
$R$. solani AG8 & $65 \mathrm{~b}$ & 0.39 & $82.6 \mathrm{~b}$ & 0.50 \\
\hline
\end{tabular}

y Three-day-old seedlings were sown on top of a whole oat kernel infested with $R$. solani AG8 or without pathogen (control) and grown for 7 day at $15^{\circ} \mathrm{C}$. Sample size $=8$. Letters indicate a significant $(P<0.05)$ differences between means within each column according to Fisher's least significant difference test (Statistix vers. 8.1, Tallahassee, FL).

${ }^{\mathrm{z}}$ Ratio of values for fresh wt (Fw) and root length (Rl) from $R$. solani-treated relative to control seedlings. of mean root fresh weight and total root length (Table 1) previously observed for cone-tainers (Okubara et al. 2009; Schroeder and Paulitz 2008). In both tube and earlier cone-tainer assays, Rz1 showed less damage from $R$. solani AG8 than did Scarlet. The inherent differences between genotypes were part of the growth response that served as a reference pattern from older cone-tainer assays, and demonstrated that our new assays could be substituted for the older one.

The smaller disposable tubes afforded several advantages to conetainers: 1) tubes eliminated the need for cutting and taping; 2) tubes required about half the volume of soil and inoculum; and 3) the reduced soil volume. These advantages allowed root symptoms to be assayed at 7 days compared with 14 days. However, root development and disease progress in the 7-day assays were not as pronounced as in 14-day assays, resulting in more variation in the mean root length response with sample sizes of 12. Partial resistance in Rz1 was better indicated using root surface area, and selection of resistant individuals could be based on this variable in future wheat screens. Alternatively, a larger sample size or lower inoculum density could be used. For instance, we found that 280 rather than $400 \mathrm{CFU} / \mathrm{g}$ soil of $R$. solani AG8 resulted in mean total root length values with the expected disease differential for Rz1 and Scarlet. This assay can be applied to screens for Rhizoctonia resistance in barley, with appropriate adjustments to inoculum density, sample size, and root growth variables. The barley response to $R$. solani AG8 has been quantified at $80 \mathrm{CFU} / \mathrm{g}$ soil in cone-tainer assays (Schroeder and Paulitz 2008).

In contrast to the ground oat assay, the whole oat kernel assay gave reproducible infection of barley seedlings, possibly because pathogen outgrowth from the kernel was remarkably robust and uniform. A potential drawback of this form of inoculum is that population density of the pathogen cannot be manipulated, as a single oat kernel represents one propagule with high inoculum potential. The oat kernel soil assay was successful for barley but not for wheat. The reason for this is unknown, but might be related to the growth dynamics and architecture of the seminal roots. For instance, roots of Golden Promise were finer than those of Scarlet and Rz1 (Chapagain et al. 2014; Okubara et al. 2009). However, the most relevant variable, seminal root branching angle (Chapagain et al. 2014), was not compared for the wheat and barley genotypes used in this study. Also, wheat and barley varieties exhibit a range of branching angles (Richard et al. 2015; Bengough et al. 2004; Chapagain et al. 2014), and the whole oat assay might not be suitable for all barley genotypes.

The use of ground oats in root coating assays arose from observations that Rhizoctonia spp. appeared to prefer agar over living roots; placing agar plugs of pathogen directly against roots of seedlings in petri plates, or infection using plugs adjacent to roots on moist paper was largely unsuccessful (Okubara, unpublished). This was also

Table 3. Responses of seedling roots of wheat cultivars 'Scarlet' (susceptible) and 'Scarlet-Rz1' (partially resistant), and barley cultivar 'Golden Promise' (susceptible) to Rhizoctonia solani AG8 in root coating assays ${ }^{\mathrm{y}}$

\begin{tabular}{lcccc}
\hline Cultivar treatment & $\begin{array}{c}\text { Fresh } \\
\text { weight }(\mathbf{m g})\end{array}$ & Fw ratio $^{\mathbf{z}}$ & $\begin{array}{c}\text { Root } \\
\text { length }(\mathbf{c m})\end{array}$ & Rl ratio $^{\mathbf{z}}$ \\
\hline Scarlet & & & & \\
$\quad \begin{array}{l}\text { Control } \\
\text { R. solani }\end{array}$ & $48 \mathrm{~b}$ & - & $32.6 \mathrm{~b}$ & - \\
$\begin{array}{l}\text { Scarlet-Rz1 } \\
\quad \text { Control }\end{array}$ & $25 \mathrm{~d}$ & 0.53 & $16.1 \mathrm{~d}$ & 0.49 \\
$\quad$ R. solani & $57 \mathrm{a}$ & - & $35.4 \mathrm{a}$ & - \\
Golden Promise & $33 \mathrm{c}$ & 0.57 & $20.4 \mathrm{c}$ & 0.58 \\
$\quad$ Control & & & & \\
$\quad$ R. solani & $49 \mathrm{a}$ & - & $58.1 \mathrm{a}$ & - \\
\hline
\end{tabular}

${ }^{y}$ Responses were quantified 3 days after coating in ground oat inoculum harboring about 40 propagules of $R$. solani AG8. Sample size $=12$ control and pathogen-challenged for wheat, and 8 control and 12 pathogen-challenged for barley. Letters indicate significant $(P<0.05)$ differences among the means for each species according to Fisher's least significant difference test (Statistix vers. 8.1, Tallahassee, FL). One representative experiment is shown.

${ }^{\mathrm{z}}$ Ratio of values for fresh wt (Fw) and root length (Rl) from $R$. solani-treated relative to control seedlings. 
noted for Rhizoctonia on vermiculite, in which hyphae was abundant on the artificial substrate, while wheat roots appeared symptomless (Gedye 2005; Gedye, unpublished). In this latter case, millet served as the inoculum substrate. Root coating assays showed promise for distinguishing susceptibility and resistance in wheat genotypes. In susceptible barley, they also produced disease, but a resistant barley line will be needed as further proof of concept.

Several coating experiments were done using barley roots generated from tissue culture (Imani et al. 2011; Okubara and Imani, unpublished). The regenerated roots were smaller in diameter than seminal roots, but were resistant to breakage and could be coated with ground oat material. After infection, however, the roots were markedly discolored and became fragile, often breaking during washing. Quantifying disease severity on regenerated barley roots will likely involve monitoring new variables, such as degree of breakage or browning. Careful pairing of regenerated roots will be needed to minimize morphological differences for "control" and "pathogen" treatments.

The tube and coating assays do not require as much space as assays using pots or cone-tainers, and can be done in any $15^{\circ} \mathrm{C}$ incubator equipped with growth lights. The assays will accelerate resistance screening while conserving time and materials.

\section{Acknowledgments}

This work was supported by German Academic Exchange Service (DAAD) grant A/13/09014, Washington Grain Commission grant 3061-4548, and USDA ARS Project Number 209022000016 00D (P.O.).

\section{Literature Cited}

Babiker, E. M., Hulbert, S. H., Schroeder, K. L., and Paulitz, T. C. 2011. Optimum timing of preplant applications of glyphosate to manage Rhizoctonia root rot in barley. Plant Dis. 95:304-310.

Bengough, A. G., Gordon, D. C., Al-Menaie, H., Ellis, R. P., Allan, D., Keith, R., Thomas, W. T. B., and Forster, B. P. 2004. Gel observation chamber for rapid screening of root traits in cereal seedlings. Plant Soil 262:63-70.

Bockus, W. W., and Shroyer, J. P. 1998. The impact of reduced tillage on soilborne plant pathogens. Annu. Rev. Phytopathol. 36:485-500.

Chapagain, T., Super, L., and Riseman, A. 2014. Root architecture variation in wheat and barley cultivars. Am. J. Exp. Agric. 4:849-856.

Cook, R. J., Schillinger, W. F., and Christensen, N. W. 2002. Rhizoctonia root rot and take-all of wheat in diverse direct-seed spring cropping systems. Can. J. Plant Pathol. 24:349-358.

Dreisigacker, S., Kishii, M., Lage, J., and Warburton, M. 2008. Use of synthetic hexaploid wheat to increase diversity for CIMMYT bread wheat improvement. Aust. J. Agric. Res. 59:413-420.
Gedye, K. 2005. Investigations into rhizoctonia root rot resistance in Aegilops tauschii and other wild wheat relatives. Ph.D. thesis. The Melbourne School of Land and Environment, University of Melbourne, Australia.

Gill, J. S., Sivasithamparam, K., and Smettem, K. R. J. 2002. Size of bare-patches in wheat caused by Rhizoctonia solani AG-8 is determined by the established mycelial network at sowing. Soil Biol. Biochem. 34:889-893.

Imani, J., Li, L., Schäfer, P., and Kogel, K.-H. 2011. STARTS - A stable root transformation system for rapid functional analyses of proteins of the monocot model plant barley. Plant J. 67:726-735.

MacNish, G. C., and Lewis, S. 1985. Methods of measuring rhizoctonia patch of cereals in Western Australia. Plant Pathol. 34:159-164.

MacNish, G. C., and Neate, S. M. 1996. Rhizoctonia bare patch of cereals: An Australian perspective. Plant Dis. 80:965-971.

Okubara, P. A., and Jones, S. S. 2011. Seedling resistance to Rhizoctonia and Pythium in wheat chromosome group 4 addition lines from Thinopyrum spp. Can. J. Plant Pathol. 33:416-423.

Okubara, P. A., Steber, C. M., DeMacon, V. L., Walter, N. L., Paulitz, T. C., and Kidwell, K. K. 2009. EMS-treated hexaploid wheat genotype Scarlet has enhanced tolerance to the soilborne necrotrophic pathogens Rhizoctonia solani AG-8 and R. oryzae. Theor. Appl. Genet. 119:293-303.

Paulitz, T. C., Smiley, R. W., and Cook, R. J. 2002. Insights into the prevalence and management of soilborne cereal pathogens under direct seeding in the Pacific Northwest, U.S.A. Can. J. Plant Pathol. 24:416-428.

Pumphrey, F. V., Wilkins, D. E., Hane, D. C., and Smiley, R. W. 1987. Influence of tillage and nitrogen fertilizer on Rhizoctonia root rot (bare patch) of winter wheat. Plant Dis. 71:125-127.

Richard, C. A. I., Hickey, L. T., Fletcher, S., Jennings, R., Chenu, K., and Christopher, J. T. 2015. High-throughput phenotyping of seminal root traits in wheat. Plant Methods 11:13.

Schillinger, W. F., Wysocki, D. J., Chastain, T. G., Guy, S. O., and Karow, R. S. 2012. Camelina: Planting date and method effects on stand establishment and seed yield. Field Crops Res. 130:138-144.

Schroeder, K. L., and Paulitz, T. C. 2006. Root diseases of wheat and barley during the transition from conventional tillage to direct seeding. Plant Dis. 90:1247-1253.

Schroeder, K. L., and Paulitz, T. C. 2008. Effect of inoculum density and soil tillage on the development and severity of Rhizoctonia root rot. Phytopathology 98:304-314.

Sharma, M., Schmid, M., Rothballer, M., Hause, G., Zuccaro, A., Imani, J., Kämpfer, P., Domann, E., Schäfer, P., Hartmann, A., and Kogel, K. H. 2008 Detection and identification of mycorrhiza helper bacteria intimately associated with representatives of the order Sebacinales. Cell. Microbiol. 10:2235-2246.

Smith, J. D., Kidwell, K. K., Evans, M. A., Cook, R. J., and Smiley, R. W. 2003. Evaluation of spring cereal grains and wild Triticum germplasm for resistance to Rhizoctonia solani AG-8. Crop Sci. 43:701-709.

Weller, D. M., Cook, R. J., MacNish, G., Bassett, E. N., Powelson, R. L., and Petersen, R. R. 1986. Rhizoctonia root rot of small grains favored by reduced tillage in the Pacific Northwest. Plant Dis. 70:70-73. 